\title{
The Role of HRM in Improving Labour Productivity: An Analysis of Manufacturing SMEs in Japan
}

\author{
Aruna S. Gamage \\ Senior Lecturer \\ Department of HRM \\ University of Sri Jayewardenepura
}

\begin{abstract}
Small and Medium Enterprise (SME) sector is considered to be the backbone of Japanese economy. Its importance is often highlighted by the large share of the economy it occupies, whether in terms of number of companies, total number of employees, value of shipments or GDP. However, since last two decades many SMEs have gone out of businesses while firm entry rate is showing downward trend. According to some business advocates, one of the reasons for high rate of business failures in SMEs is due to its less attention to the human side of their businesses. Therefore, the broad objective of this study is to examine the role of Human Resource Management (HRM) practices in SMEs in Japan. Specifically, this study attempts to examine the relationship between HRM practices and labor productivity in manufacturing SMEs in Japan. Further, it aims to examine the mediating link of HR outcomes in between HRM practices and labour productivity. A structured questionnaire was developed and sent to 436 SMEs in Aichi Prefecture and 144 firms responded to the questionnaire resulting in 32 percent response rate. Based on the data analysis it was found that there is a strong positive relationship between HRM practices and labour productivity mediated by HR outcomes in manufacturing SMEs in Japan.
\end{abstract}

Key Words: Human Resource Management, Small and Medium Enterprises, HR Outcomes, Labour Productivity.

\section{Introduction}

Small and Medium Enterprise (SME) sector is considered as the backbone of Japanese economy. It has been playing a major role in every area of its national economy. The importance of this sector is indicated by the very large share of the economy that it occupies, whether in terms of number of companies, total number of employees or value of shipments or GDP. There are 4.69 million SMEs in Japan, constituting 99.7 percent of all enterprises, accounting for 70 percent of all employment (Small and Medium Enterprise Agency, 2013). Although most people are familiar with large companies such as Toyota, Sony, and DoCoMo, it is the small and medium enterprises (SMEs) that drive Japanese economy. Although their relative importance as a share of the number of enterprises and the number of employees is declining compared with the situation at the beginning of the 2000 s, there is no change in the fact that the SME sector still accounts for the vast majority of enterprises and employees in Japan. Large enterprises (LEs) such as Toyota, Honda, and Sony etc. originally began as small family businesses (Sato, 2013). The revitalization of SMEs promotes competition in the market and can be the driving force in creating new industries and transforming the industrial structure. The majority of products of 
LEs are made up of parts produced by SME subcontractors, and therefore, the availability and reliability of Japanese products are supported by the underlying strength of SMEs.

During the last two decades, SMEs have no longer been a thriving source of growth. The number of manufacturing establishments employing 4 to 299 people steadily declined from 434,754 in 1985 to 254,675 in 2007. The sharp decline in the number of establishments was caused not only by the failure of enterprises but also by the lower number of enterprises entering the economy. As shown in Figure 1, the entry rate has experienced a prolonged decline while the firm exit rate has trended upward in recent years, and rose by a record annual average of 6.0 percent (based on the number of enterprises) between 2001 and 2004. As a consequence, the firm exit rate has considerably exceeded the firm entry rate despite the slight upward swing in the entry rate (METI, 2006).

Nevertheless, successful business management of SMEs largely depends on the quality of human resources that supports companies (JASMEC, 2001). Securing and training high quality personnel are, therefore, key factors for the growth of SMEs, which often have limited opportunities to utilize managerial resources. The organizational effectiveness of the firm (Huselid, 1995; Terpstra and Rozell, 1993) and its ability to create a sustainable competitive advantage (Prahalad, 1983; Pfeffer, 1994) can hinge upon whether HRM practices are properly thought out and successfully implemented. But, in general, it is argued that SMEs are paying less attention to HRM practices when compared with their counter parts of large enterprises (Kok, 2003; Wong et al, 1997; Gamage, 2007). Therefore, the prime objective of this study is to examine the role of HRM practices in SMEs in Japan. Specifically, this study attempts to examine the relationship between HRM practices and labor productivity, which is one of the critical factors that determines the success of any business organization. Further, it aims to examine the mediating link of HR outcomes in between HRM practices and labour productivity.

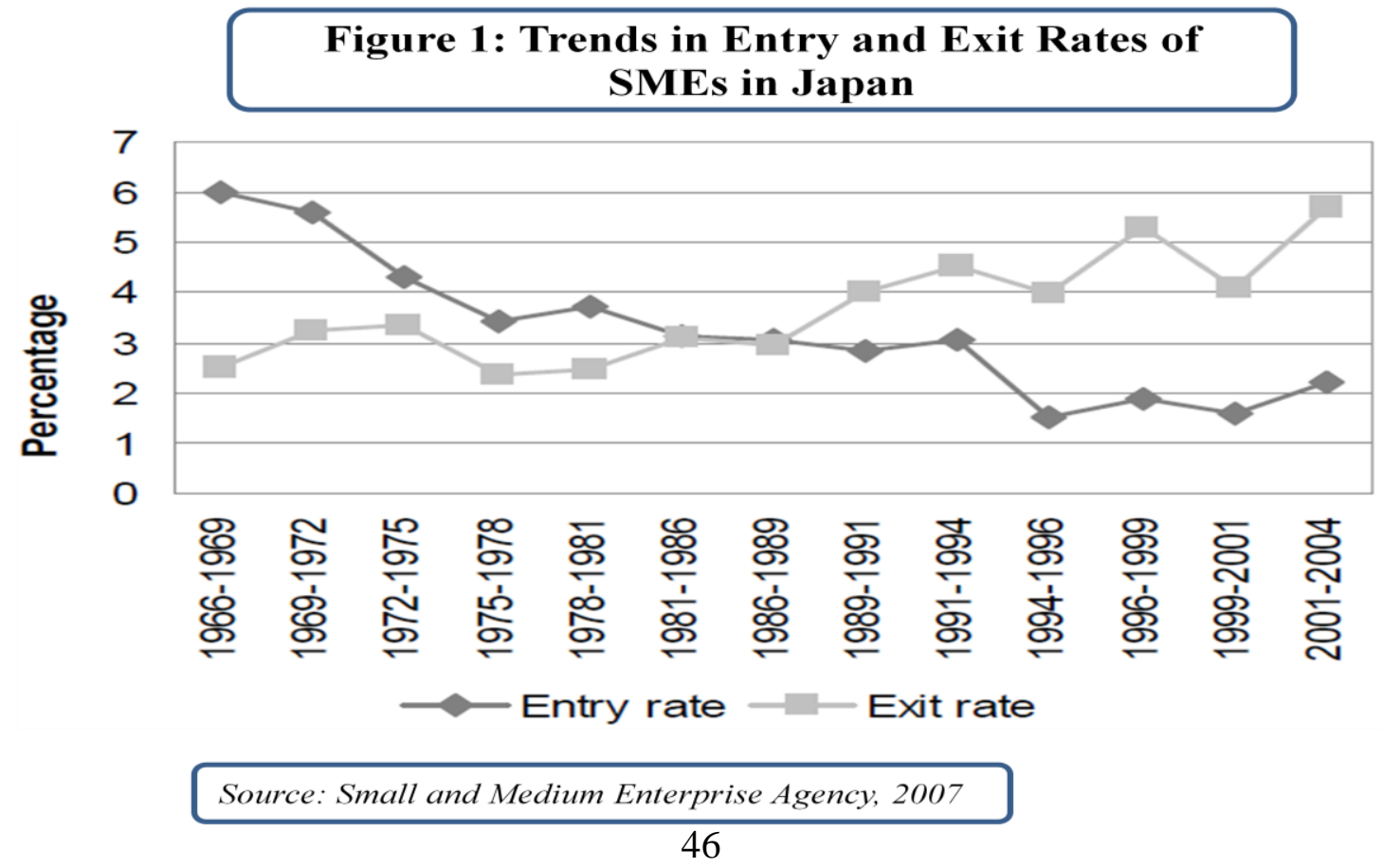




\section{Literature Review}

This section presents an overview of research in HRM in SMEs and subsequently, briefly presents main conclusions of studies conducted on the relationship between HRM practices and labour productivity within SME business context.

\section{HRM in SMEs}

Given the importance of SMEs employees to the national economy, it is disheartening to note that scant attention in SMEs research is given to the study of human resource management practices. No matter where you look, in surveys (e.g., Hornsby and Kuratko, 1990), in reviews of literature (e.g., Good, 1998), and in empirical studies (Heneman and Berkley, 1999), scholars are lamenting over the dearth of information about human resource management practices in SMEs. Proper management of a company's human resources is the key to business survival in today's world. The organizational effectiveness of the firm (Huselid, 1995; Terpstra and Rozell, 1993) and its ability to create a sustainable competitive advantage (Prahalad, 1983; Pfeffer, 1994) can hinge upon whether HRM practices are properly thought out and successfully implemented. The human potentials in a company are generally much more difficult for competitors to duplicate than the plant, equipment or even products that a company produces (Flanagan and Despanade, 1996). Consequently, the nature and well being of a company's employees can become its main strength in carving out a profitable existence in the industry. HRM practices can be particularly important for small firms (Marlow and Patton, 1993) since they tend to be so dependent on human capital. Research indicates that inadequate and insufficient management of employees in small firms has resulted in low productivity and high turnover rates (Mathis and Jackson, 1991) and is one of the leading causes of small business failures (McEvoy, 1984).

The overall goal of human resource management is to ensure that the company will be able to achieve success through people. HRM aims to increase the effectiveness and organizational skills, which means the ability of an organization to achieve its goals using the available resources in the best way possible. Some authors in their studies have found that HRM systems can be the source of firms' organizational capabilities that allow one to learn and benefit from new opportunities. The generic purpose of HRM is to generate and retain appropriate and contented workforce who gives the maximum contribution to the organizational success (Opatha, 2010). Therefore, appropriately qualified, motivated and happy staff are the main factor for the success of SMEs. And also, effective HRM system helps organization attract and hire suitably qualified people and keep their knowledge, skills and attitudes updated.

Understanding the relationship between HRM and organizational performance is one of the longstanding goals of macro HRM research. Indeed, Becker and Huselid (1998) considered this relationship as one of the essential pursuits of strategic HRM research. Strategic HRM research suggests that different types of outcomes may not necessarily have equivalent relationships with HR practices (Becker and Huselid, 1998; Delery and Shaw, 2001; Guest, 1997; Lepak, Liao, Chung, and Harden, 2006; Ostroff and Bowen, 2000). Moreover, it is commonly asserted that HRM may influence three types of organizational outcomes in sequence. For example, HR practices are expected to first influence HR outcomes (e.g., employee skills and motivation), 
which are proximal and the least likely to be contaminated by factors beyond HR practices. HR outcomes, in turn, may mediate the influence of HR practices on productivity, quality, service, safety, innovation, and other operational outcomes, which further affect financial outcomes.

Operational performance is important to business leaders because it is an indication of the effectiveness and efficiency with which the company is providing its particular products or services. Several measures of operational performance are usually used for studies: labour productivity (LP), product quality (PQ), new product development (NPD), and customer satisfaction (CS). Each is a measure of how the company performs in relation to its competitors who were the similar organizations in those areas. However, this study is concerned only with labor productivity which is the most fundamental operational performance.

\section{Labour Productivity}

Labour productivity is a measure of efficiency of the organization in utilizing its human resource. Productivity is the ratio of the total output to the total input, which shows how the organization is working at a particular point of time. Therefore, labor productivity is the total quantity of goods and services that an employee produces in a given amount of time. It is computed by dividing average output per period by the total number of personnel employed in that period. It is just one type of productivity among several others. However, labor productivity is used most often because of number of reasons. First, labor productivity is used as the most fundamental organizational outcome. Secondly, there is a big connection between the productivity and the human capital and the most important connection is with the productivity of the labor. There is a direct link between the two so it is the most valid tool that can be used to measure the success rate of the organization (Dyer and Reeves, 1995). Third, the theorists pertaining to Strategic Human Resource management (SHRM) have elaborated the point that for workforce performance, productivity of labor is a crucial indicator (Delery and Shaw, 2001). Finally, in literature pertaining to SHRM much work has been accomplished using labor productivity as tool to calculate outcome (Boselie and Dietz, 2003).

Employee productivity is a measure of the efficiency of employees in converting inputs into useful outputs. Productivity is a critical determinant of cost efficiency. Therefore, increasing productivity is one of the most critical goals in business. High-performing and innovative employees are the foundation of productivity. The most impactful factor in workforce and team productivity is hiring and retaining employees with exceptional capabilities and self-motivation.

Several studies have found that HRM practices have a positive effect on labour productivity, although there is usually no clear effect attributable to specific practices (Youndt, Snell, Dean and Lepak, 1996; Ichniowski et al, 1997). The latter might be due to multi co-linearity among the various HRM practices, as several practices are strongly correlated (Wolf and Zwick, 2002), or may reflect the argument that only consistent bundles of HRM practices are effective (Arthur, 1994; MacDuffie, 1995; Ichniowski, Shaw and Prennushi, 1997). Some studies show that certain HRM practices, such as working in teams, greater discretion and autonomy in the workplace and various employee involvement and pay schemes, do motivate workers and generate higher labor productivity (Cully et al, 1999; Boselie and Wiele, 2002). Employees' involvement in terms of 
delegation of responsibility and systems of collecting proposals from employees may have a positive impact on productivity (Arthur, 1994).

Arthur (1994) found that steel mills that use an HRM 'commitment system' have higher productivity levels than those that do not. Others have found that the HRM practices have significant positive effects on firm productivity (Huselid, 1995; Ichniowski, et al, 1997; Batt, 2002; Wolf and Zwick, 2002).

Several arguments can be found in the HRM literature, for the expected positive relation between HRM practices and a firm's productivity (e.g. Wolf and Zwick, 2002). First, investments in the human capital of the workforce may increase the productivity of workers (e.g. Bartel, 1994). Second, 'good' HRM policies may increase the motivation of workers (Ichniowski et al, 1997; Wood, 1999). Third, increasing the autonomy and responsibilities of the workers may diminish waste and inefficiencies because it enables the firm to take advantage of the specific knowledge of non-managerial workers (Appelbaum, Berg, Bailey and Kalleberg, 2000; Preuss, 2003). Fourth, 'good' HRM policies may contribute to workers' commitment to their tasks and willingness to do a better job (Ichniowski et al, 1997). Batt (2002) supports this argument and its application to the service sector. She found that high commitment of the workforce contributes to the effectiveness of employee-customer interaction in service-sector firms. Fifth, good HRM policies reduce quit rate, which, in turn, decreases recruitment and selection costs, and increases the benefits of investments in firm-specific skills. Moreover, in the service sector, employee turnover might induce customer turnover (Arthur, 1994; Huselid, 1995; Batt, 2002). Finally, giving more responsibility to the work floor enables the firm to delayer the organization, thereby reducing the costs of the middle management (Appelbaum et al, 2000).

\section{Human Resource Management Practices}

Human Resource Management (HRM) is the function within an organization that focuses on recruitment of, management of, and providing direction for the people who work in the organization. It is the effective and efficient utilization of human resources to achieve organizational objectives (Opatha, 2010). HRM is the human side of the organizational management. It is mostly responsible for the attraction, selection, training, assessment, and rewarding of employees for getting maximum contribution toward the organizational success. Stone (2005) defined human resource management as productive use of people in achieving the organization's strategic business objectives and the satisfaction of individual employees. This definition clearly indicates that the organizations' objectives are dependent on their work force productivity. The effective use of HRM practices enables to link these practices with organization's goals and objectives. In order to accurately measure "human resource practices", a number of HR functions may need to be evaluated. The importance of these practices may differ from firm to firm. One of the most comprehensive and widely used measures for human resource practice was presented by Dessler (2008) and Fisher et al (2006). In their studies, human resource management practices are characterized as multidimensional, and it has four major facets namely; staffing, training and development, employee performance evaluation, and compensation of employees. 


\section{Staffing}

Staffing is the process of acquiring, deploying, and retaining a workforce of sufficient quantity and quality to create positive impacts on the organization's effectiveness. It involves recruitment, selection, hiring and induction of potential employees. Recruitment is the process of finding and attracting suitably qualified people to apply for job vacancies in the organization (Based on Opatha, 2010). It is a set of activities an organization uses to attract job candidates who have the needed abilities and attitudes (Based on Glueck, 1979 as in Opatha, 2010). Selection is the process of making the choice of the most appropriate person from the pool of applicants recruited to fill the relevant job vacancy (Opatha, 2010). Hiring is the process appointing selected candidates to the posts which are vacant. Induction is the HRM function that systematically and formally introduces the new employee to the organization, to the job, to the work group to which new employee will belong and the work environment where the new comer will work (Based on Opatha, 2010). Various tools and techniques are used by firms for the improvement of staffing process to avoid the loss in terms of time, money and potential employees.

\section{Training and Development}

Training and development is another dimension of human resource practices where firms invest on development of their employees' knowledge, skills ability and other required skills to improve the productivity of employees. Training and Development is the HRM function that formally and systematically provides new learning to increase employees' capabilities. The primary purpose of training and development is to increase organizational performance by increasing employee performance. Training and development can transform human resource to human capital where skilled employee would better perform in the success of organization as compared with none or less- trained employees.

\section{Performance Evaluation}

Performance evaluation is defined as the systematic process of identifying, measuring, influencing, and developing job performance of the employees in the organization in relation to the set of norms and standards for a particular period of time in order to achieve various purposes (Opatha, 2010).This aspect of human resource practices generally involves the activities of various evaluation designs, both formal and informal, and different evaluation periodicities (Shub and Stonebraker, 2009). It is a means of getting better results by understanding and managing performance within an agreed framework of planned goals, standards and competency requirements. It functions as a continuous and evolutionary process, in which performance improves over time. Moreover, it provides the basis for regular and frequent dialogues between managers and individuals about performance and development needs (Armstrong, 2006).

\section{Compensation management}

Compensation is the total amount of the monetary and non-monetary pay provided to an employee by an employer in return for work performed as required. It is one of the most extrinsic practices of human resource function in an organizational setting. Compensation may include payments such as bonuses, profit sharing, overtime pay, recognition rewards, and sales commissions etc. Compensation can also include non-monetary perks such as a company-paid car, stock options in certain instances, company-paid housing, and other non-monetary items. This dimension determines the level of job of an employee on the basis of their perceived 
knowledge and experience. Moreover, the matching of their job knowledge with the pay or compensation provided them must demonstrate the market level competitive packages. Good compensation plan would therefore, inevitably influence on employees' performance. However, the extent to which an employee who is getting the good compensation package will perform well would also depend on his or her overall assessment of various factors like the compensation package in other organizations in relation to the work load and the possibility of getting better compensation packages (Purani and Sahadev, 2008).

Huselid (1995) in his study comprehensively evaluated the links between systems of High Performance Work Practices (HPWP) and firm performance. Results based on a national sample of nearly one thousand firms indicate that these practices have an economically and statistically significant impact on both intermediate operational outcomes (turnover and productivity) and short-and long-term measures of corporate financial performance. Katz, Kochan, and Weber (1985) demonstrated that highly effective industrial relations systems, defined as those with fewer grievances and disciplinary actions and lower absenteeism, increased product quality and direct labor efficiency and Katz, Kochan, and Keefe (1987) showed that a number of innovative work practices improved productivity. Katz, Kochan, and Gobeille (1983) and Schuster (1983) found that quality of work life (QWL), quality circles, and labor-management teams increased productivity. Bartel (1994) established a link between the adoption of training programs and productivity growth, and Holzer (1987) showed that extensive recruiting efforts increased productivity. Guzzo, Jette, and Katzell's (1985) meta-analysis demonstrated that training, goal setting, and socio technical systems design had significant and positive effects on productivity.

\section{Conceptual Framework and Methodology}

For the study, four (4) HRM practices namely; employee staffing, training and development, performance management, compensation management were selected. Then, the relationship between HRM practices and labour productivity was examined exploring the mediating relationship of HR outcomes. Based on the above theoretical underpinning, a conceptual frame for the study was constructed as in Figure 2. According to the model in Figure 2, HRM practices have direct relationship with HR outcomes and then these HR outcomes have relationship with employee productivity. The model goes on explaining the process through which HRM practices are linking with organizational performance. The Figure shows possible reversed causality which was not really examined in this study as it is beyond the objectives of the study.

A structured questionnaire was developed as the main data collection instrument. As mentioned above, four (04) HRM practices including employee staffing, training and development, performance management, compensation management were selected for the purpose of study. These four HRM practices were the most widely discussed HRM practices in the literature. In order to examine the HRM intensification, forty (40) items (employee staffing, 10; training and development, 12; performance management, 10; and Compensation management, 8) were included in the questionnaire. Nine (9) HR outcomes; knowledge quality (KQ), occupational health and safety (OHS), job satisfaction (JS), employee commitment (EC), employee attitudes (EA) employee motivation (EM), employee loyalty (EL), employee involvement (EI)), and workplace cooperation (WC) were considered for the study. Three (3) items for each HR outcome variables were included in the questionnaire. Four items in the scale were used in order 
to measure labor productivity. The questionnaire was first developed in English and then translated into Japanese to make respondents better understand it.

Four hundred thirty six (436) questionnaires were distributed to a randomly selected sample of manufacturing SMEs in Nagoya in Aichi Prefecture. An electronic data file maintained by the Nagoya Chamber of Commerce was used to draw the sample. One hundred forty four (144), equivalent to thirty two percent (32 percent), responded to the survey. Data was analyzed by using SPSS version 16. Descriptive statistics were used to understand the characteristics of firms and person product movement correlation coefficient was used to examine the relationships among variables.

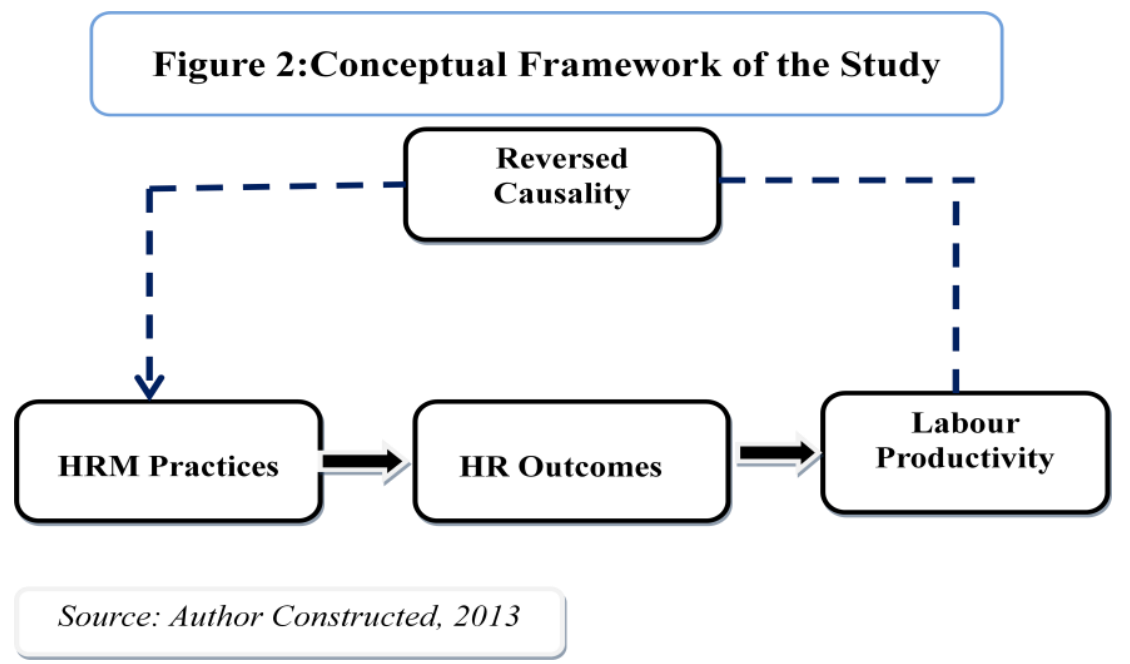

\section{Reliability and Validity of the Questionnaire}

In order to measure the reliability of instruments, Cronbach's alpha coefficient is widely used. According to Sekaran (2005), if the alpha value is greater 0.7, the instrument is said to be acceptable. The internal consistency reliability coefficients (Cronbach's alpha) for the scales used in this study are well above the level of 0.7 . Table 1 shows coefficients for all variables. According to table 1 , each variable has got more than 0.8 alpha values which are well above the standard and thus are acceptable for the analysis purpose. Validation procedures involved initial consultations with subject matter experts about the questionnaire prepared. The experts also judged the face and content validity of the questionnaire and decided as adequate. Hence, the researcher was satisfied with the reliability and validity of the scale.

\section{Results of the Survey}

\section{HRM Practices, Labour Productivity and HR Outcomes}

Table 2 shows Pearson product movement correlation coefficients among HRM practices, labour productivity and HR outcomes. According to the Table 2, HRM practices are highly and positively correlated to labour productivity. First, employee staffing shows positive correlation with labour productivity. This relationship is strong and statistically significant $(r=.357, p<$ 
0.01.). Second, the correlation of training and development with labour productivity is also positive and very high $(\mathrm{r}=.340, \mathrm{p}<0.01)$. The link between training and development and labour productivity is strong and statistically significant. Third, performance evaluation function also establishes strong correlation with labour productivity $(\mathrm{r}=.417, \mathrm{p}<0.01)$. This relation is also positive and statistically significant. Finally, the relationship in between compensation management and labour productivity is also very strong $(\mathrm{r}=.289, \mathrm{p}<0.01)$. Although the magnitude of coefficient is somewhat lower when compared with three other coefficients, it is also positive and statistically significant. Among all these four practices, it is performance evaluation practice which has the highest magnitude of the relationship while compensation records the lowest.

In order to examine the mediating relationship in between HRM practices and labour productivity, HR outcomes were studied. Based on the nine HR outcomes, a cumulative index that represents the aggregation of all nine HR outcomes was developed. The links between HRM practices and HR outcome index were examined. Not surprisingly with earlier studies, this study too establishes very strong correlations in between all four HRM practices and HR outcomes, (Employee staffing, $\mathrm{r}=.488, \mathrm{p}<0.01$; Training and development, $\mathrm{r}=.462, \mathrm{p}<0.01$; performance evaluation, $\mathrm{r}=.483, \mathrm{p}<0.01$; and compensation management, $\mathrm{r}=.406, \mathrm{p}<0.01$ ). On the other hand, the correlations of HR outcomes and labor productivity also cannot be undermined. HR outcome index shows very high and positive correlation with labor productivity which is $r=.631$ $(p<0.01)$. This link is also statistically significant indicating the fact that the link is in presence not by chance but worthy of further studying.

Table 1: Reliability Analysis

\begin{tabular}{|c|c|}
\hline Variable & Cronbach Alpha \\
\hline Employee Staffing (10) & 0.916 \\
\hline Training \& Development (12) & 0.941 \\
\hline Performance Evaluation (10) & 0.939 \\
\hline Compensation Management (8) & 0.871 \\
\hline HRM Outcomes (18) & 0.921 \\
\hline Labour Productivity (4) & 0.942 \\
\hline
\end{tabular}

Source: Survey Data, 2013 
Table 2: Correlations among Variables

\begin{tabular}{|l|l|r|r|r|l|}
\hline \multicolumn{7}{|l|}{ Correlations among Variables } \\
\hline VARIABLE & ES & TD & PE & CM & HROC \\
\hline Employee Staffing (ES) & 1 & & & & \\
\hline Training \& Development (TD) & $.794^{* *}$ & & & & \\
\hline Performance Evaluation (PE) & $.702^{* *}$ & $.632^{* *}$ & & & \\
\hline Compensation Management (CM) & $.600^{* *}$ & $.581^{* *}$ & $.724^{* *}$ & & \\
\hline HR Outcomes (HROC) & $.458^{* *}$ & $.462^{* *}$ & $.483^{* *}$ & $.406^{* *}$ & \\
\hline Labour Productivity (LP) & $.357^{* *}$ & $.340^{* *}$ & $.417^{* *}$ & $.289^{* *}$ & $.631^{* * *}$ \\
\hline **. Correlation is significant at the 0.01 level (2-tailed). \\
*. Correlation is significant at the 0.05 level (2-tailed). \\
\hline
\end{tabular}

Source: Survey Data, 2013

\section{Discussion of Findings}

\section{HRM practices and Labour Productivity}

In this study the four areas of HRM practices have highlighted their role and their relationships with labour productivity. Similar to the findings of earlier studies in large organizations, this study also establishes very strong and statistically positive correlations between HRM practices and labour productivity in manufacturing SMEs in Japan. According to the findings, all four HRM practices were highly and positively correlated with labour productivity. It implies the idea that four HRM practices; employee staffing, training and development, performance evaluation, and compensation management have positive relations with labour productivity. This highlights that an increase of the usage of above HRM practices gives rise to higher productivity. As all these relations are positive, with the increase of the usage of the said HRM practices, labour productivity will be increased. Therefore, the conclusion that can be drawn from this finding is that, SME owners/managers who are concerned about increasing labour productivity should be prepared to engage in effective usage of HRM practices discussed above.

\section{HRM Practices and HR outcomes}

Analysis of the data clearly establishes very high positive correlations of HR outcomes with labor productivity. Therefore, it is intuitive to assume that HR outcomes are playing a mediating relationship in between HRM practices and labour productivity. With this correlation, it is reasonable to assume an increase of the usage of above HRM practices gives rise to higher productivity through HR outcomes. Drawing from these findings, it can be concluded that those owners/managers in SMEs who are concerned to increase their labour productivity should focus once again on effective use of HRM practices prescribed above. However, in order to examine the impact of mediating effect of HR outcomes further analysis with sophisticated statistical techniques is needed. 


\section{Implications, Limitations and Directions, for Future Research}

The results of this study offer several key theoretical and practical implications for SMEs owners and managers interested in improving labour productivity in their SMEs. Effective HRM practices lead to positive HR outcomes. The effective use of HR practices; employee staffing, training and development, performance management, and compensation management in SMEs was shown to be correlated to HR outcome index which was represented by knowledge quality, occupational health and safety, job satisfaction, employee commitment, employee attitudes employee motivation, employee loyalty, employee involvement and workplace cooperation. These positive HR outcomes in turn are translated into positive operational performance such as increase in labour productivity. This highlights the fact that employees do matter even for SMEs and are shown to have links with labour productivity in their businesses. Therefore, as the study highlights, when evaluating many options that are available to SMEs, it is very important to keep in mind not to discount the importance of human resource management. Effective human resource management practices lead directly to positive outcomes on employees of the firm, which in turn lead to positive operational performance for the organization.

This study is subject to certain limitations encountered in the research process. The study was based on the data collected only from 144 manufacturing SMEs in Aichi prefecture Japan. Therefore, generalisability could have been increased if a larger number of manufacturing firms representing all the prefectures in Japan had been taken. This study focused only on the relationships, not on the effect or impact, between HRM practices and labour productivity. However, it could have been better if this study had focused on the effect of HRM practices on labour productivity too. Further analysis with sophisticated statistical testing is sought to examine the impact of HRM practices on operational performance and mediating role of HR outcomes. However, future research with relatively larger samples expanding to other sectors in SMEs will be more useful indeed in this direction.

\section{References}

Appelbaum, E., Berg, P., Bailey, T., and Kalleberg, A. L. (2000), Manufacturing Advantage: Why High Performance Systems Pay Off, Ithaca: ILR Press.

Armstrong, M. (2006), A Handbook of Human Resource Management Practice, 10th ed., London: Kogan Page.

Arthur, J. B. (1994), Effects of Human Resource Systems on Manufacturing Performance and Turnover, Academy of Management Journal, Vol. 37, pp. 670-687.

Batt, R. (2002), Managing Customer Services: Human Resource Practices, Quit Rates, and Sales Growth, Academy of Management Journal, Vol. 45, pp. 587-597.

Bartel, A. P. (1994), Productivity Gains from the Implementation of Employee Training Programs, Industrial Relations, Vol. 33, pp. 411-425. 
Becker, B. E., and Huselid, M. A. (1998), High Performance Work Systems and Firm Performance: A Synthesis of Research and Managerial Implications. In G. R. Ferris (Ed.), Research in personnel and human resources management, Greenwich, CT: JAI Press.

Boselie, P., and Van der Wiele,T. (2002), Employees Perception of HRM and TQM, and the Effects on Satisfaction and Intention to Leave, Managing Service Quality, Vol. 12, No. 3, pp. 165-172.

Boselie, P., and Dietz, G. (2003), Commonalities and Contradictions in Research on Human Resource Management and Performance, Academy of management meeting. Sattle: USA.

Cully, M., Woodland, S., O'Reilly, A., and Dix, G. (1999), Britain at Work: As depicted by the 1998 Workplace Employee Relations Survey, Routledge: London.

Delery, J. E., and Shaw, J. D. (2001), The Strategic Management of People in Work Organizations: Review, Synthesis, and Extension. In G. R. Ferris (Ed.), Research in personnel and human resource management, Vol. 20, pp. 167-197.

Dessler, G. (2008), Human Resource Management, 11th ed., NJ: Pearson Prentice-Hall, Upper Saddle River.

Dyer, L., and Reeves, T. (1995), Human Resource Strategies and Firm Performance: What Do We Know and Where Do We Need to Go? International Journal of Human Resource Management, Vol. 6, pp. 656-670.

Fisher, C. D., Schoenfeldt, L. F., and Shaw, J. B. (2006), Human Resource Management, 6th ed., Boston, MA: Houghton Mifflin.

Flangan D. S., and Despande, S. P. (1996), Top Management's Perceptions of Changes in HRM Practices after Union Elections in Small Firms, Journal of Small Business Management, Vol. 34, No. 4, pp. 23-34.

Gamage, A.S. (2007), Impact of HRD Practices on Business Performance: An Empirical Analysis of Manufacturing SMEs in Japan, Meijo Review, Vol. 8, No. 3, pp. 85-109.

Good, D. C. (1998), Gender and Successful Human Resource Decision in Small Business, New York: Garland publishing.

Guest, D. E. (1997), Human Resource Management and Performance: A Review and Research Agenda, International Journal of Human Resource Management, Vol. 8, pp. 263-276.

Guzzo, R. A., Jette, R. D., and Katzell, R. A. (1985), The Effect of Psychologically Based Intervention Programs in Worker Productivity: A Meta-analysis. Personnel Psychology, Vol. 38, pp. 275-291. 
Henman, H. G. III., and Berkley, R.A. (1999), Applicant Attraction Practices and Outcomes among Small Businesses, Journal of Small Business Management, Vol. 37, No. 1, pp. 5374.

Honsby, J. S., Kuratko, D.K. (1990), Human Resource Management in Small Business: Critical Issues for the 1990s, Journal of Small Business Management, Vol. 28, pp. 9-18.

Huselid, A. M. (1995), The Impact of Human Resource Management Practices on Turnover, Productivity, and Corporate Financial Performance. Academy of Management Journal, Vol. 38, No. 3, pp. 635-672.

Ichniowski, C., Shaw, K., and Prennushi, G. (1997), The Effects of Human Resource Management Practices on Productivity: A Study of Steel Finishing Lines. American Economic Review, Vol. 87, pp. 291-312.

JASMEC, (2001), Role of Japanese SMEs: What is SMEs? Tokyo.

Jorgensen, F., Hyland, P., and Kofoed, L. (2008), Examining the Role of Human Resource Management in Continuous Improvement, International Journal of Technology Management, Vol. 42, No. 1\&2, pp. 127-142.

Katz, H. C., Kochan T. A., and Gobeille, K. R. (1983), Industrial Relations Performance, Economic Performance, and QWL Programs: An Interplant Analysis, Industrial and Labor Relations Review, Vol. 37, pp. 3 - 17.

Katz, H. C., Kochan T. A., and Keefe, J. H. (1987), Industrial Relations and Productivity in the U.S. Automobile Industry, Washington DC: Brookings Institution.

Katz, H. C., Kochan T. A., and Weber, M. R. (1985), Assessing the Effects of Industrial Relations Systems and Efforts to Improve the Quality of Working life on Organisational Effectiveness, Academy of Management Journal, Vol. 28, pp. 506-526.

Kok, J.D. (2003), Human Resource Management within Small and Medium-sized Enterprises. Amsterdam: Rozenberg Publishers.

Mathis, R. L., and Jackson, I. H. (1991), Personnel/Human Resource Management. St.Paul, Minn: West Publishing Company.

MacDuffie, J. P. (1995), Human Resource Bundles and Manufacturing Performance: Organizational Logic and Flexible Production Systems in the World Auto Industry, Industrial and Labor Relations Review, Vol. 48, pp.197-221.

McEvoy, M. G. (1984), Small Business Personnel Practices, Journal of Small Business Management, Vol. 22, No. 4, pp. 1-8. 
McGrath, R. G. (2001), Exploratory Learning, Innovative Capacity and Managerial Oversight, Academy of Management Journal, Vol. 44, pp. 118-131.

Marlow, S., and Patton, D. (1993), Managing the Employment Relationship in the Small Firm: Possibilities for Human Resource Management, International Small Business Journal, Vol, 11, No. 4, pp. 57-64.

METI, (2006), White paper on SMEs in Japan 2006, Japan Small Business Research Institute: Tokyo.

Opatha, H.H.D.N.P. (2010), Human Resource Management, Colombo: Author published.

Pfeffer, J. (1994), Competitive Advantage Through People: Unleashing the Power of the Workforce, Harvard Business School press: Boston.

Prahalad, C.K. (1983), Developing Strategic Capability: An Agenda for Top Management, Human Resource Management, Vol. 22, No. 3, pp. 237-254.

Preuss, G. A. (2003), High Performance Work Systems and Organizational Outcomes: The Mediating Role of Information Quality, Industrial and Labor Relations Review, Vol. 56, pp. 590-605.

Purani, K. and Sahadev, S. (2008), The Moderating Role of Industrial Experience in the Job Satisfaction, Intention to Leave Relationship: An Empirical Study Among Salesmen in India, Journal of Business and Industrial Marketing, Vol. 23, No.7, pp. 475-485.

Sato, K. (2013), Japan's Policies for Small and Medium Enterprises, Economic Attache Embassy of Japan in the KSA: KSA.

Schuster, M. (1983), The Impact of Union-management Cooperation on Productivity and Employment, Industrial and Labor Relations Review, Vol. 36, pp. 415-430.

Sekaran, U. (2005), Research Methods for Business: A Skill Building Approach, New York: John Wiley and Sons.

Shipton, H., Fay, D., West, M., Patterson, M. and Birdi, K. (2005), Managing People to Promote Innovation, Creativity and Innovative Management, Vol. 14, No. 2, pp. 118-128.

Shub, A. N., and Stonebraker, P. W. (2009), The Human Impact on Supply Chains: Evaluating the Importance of "Soft" Areas on Integration and Performance, Supply Chain Management: An International Journal, Vol.14, No. 1, pp. 31-40.

SMEs Agency, (2013), Contribution of SMEs to the National Economy of Japan, Retrieved from http://www.chusho.meti.go.jp/sme_english.

Stone, R. J. (2005), Human Resource Management, 5th ed., Australia: John Wiley \& Sons. 
Tan, C. L., and Nasurdin, A. M. (2010), Human Resource Management Practices and Organizational Innovation: An Empirical Study in Malaysia. Journal of Applied Business Research, Vol. 2, No. 4, pp. 105-115.

Terpstra, E. D., and Rozell, J. E. (1993), The Relationship of Staffing Practices to Organizational Level Measures of Performance, Personnel Psychology, Vol. 46, No. 1, pp. 27- 48.

Wong, C., Marshall, N., Alderman, N. and Thwaites, A. (1997), Management Training in Small and Medium-sized Enterprises: Methodological and Conceptual Issues', International Journal of Human Resource Management, Vol. 8, No. 1, pp. 44-65.

Wood, S. (1999), Human Resource Management and Performance. International Journal of Management Reviews, Vol. 1, pp. 367-413.

Youndt, M.A., Snell, S.A., Dean jr., J.W., and Lepak, D. P. (1996), Human Resource Management Manufacturing Strategy and Firm Performance, Academy of Management Journal, Vol. 39, pp. 836-86. 